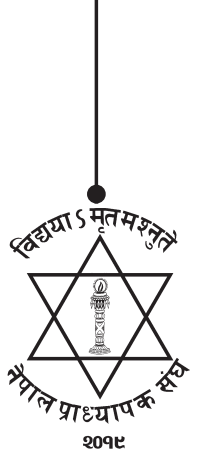

NJ: NUTA

\title{
Social Security System of Elderly Population in Nepal
}

\author{
Kamala Bhandari \\ Lecturer, Patan Multiple Campus, TU, Kathmandu \\ Email for correspondence:bhandarik@gmail.com
}

\begin{abstract}
Population is classified as aging when older population become a proportionately larger share of the total population where as social security refers to the financial support action programme of Government intended to promote welfare of the population that is potentially directed to vulnerable segment of the society such as children, the elderly, the sick and the unemployed. It is the tool for the government to take care of well being of it's citizen. Population aging generates many challenges. In response to tackle these issues and to address their needs the Government has developed the social security policies, plan and acts. The main objective of this paper is to discuss on process of aging and the policy issue related to social security of old age population in Nepal.
\end{abstract}

This paper follows descriptive and analytical method based on the secondary data. The data from these sources are used to analyze the trend and process of aging and social security system in Nepal. Furthermore this paper is based on review of literature mainly books, journal, article and report.

Nepal is already in the process of population aging. population aging generates many challenges on social, economic and health care system. In response to tackle these issues and to address their needs the Government of Nepal has formulated separate policies and security programme for senior citizen and also committed to the various regional and international convention to promote welfare for senior citizen of the country.

Key Words: Elderly population, Social Security and policy.

\section{Background}

Worldwide population aging has been considered one of the most important demographic phenomena that the older people is increasing almost all of the world. It is the dynamic process of demographic and socioeconomic transformation which reflects the increasing in the share of the elderly population aged 60 and over on the total population. It is considered as the natural process. The combined effect of lowered fertility and improved health and longevity has generated growing numbers and the proportion of older population through out the world. Both the developed and developing countries of the world are experiencing the population aging and there is growing concern about the population aging in the world,(UNFPA,2012). 
Globally the proportion of older persons is growing at faster rate then the general population. With one in nine persons in the world aged 60 and over projected to increase to one in five by 2050 . By 2012 the number of older increased to almost 810million (205 millionin1950)and projected to reach 2 billion by 2050,(UNFPA 2012). During 2010 to 2015 the average annual growth rate of global population aged 60 or over was almost three times(3.3\%) that recorded for the total population(1.1\%) that climbed from 2.0 percent per year during 2000 to 2005 (UN,2015).Hence population aging is a phenomenon that we can no longer ignore.

Population aging is recognized as one of the most prominent feature of population growth in Nepal. Nepal is facing rapid decline in fertility, remarkable improvement in mortality and a large migration of economically active population in the third countries as a consequences increasing number of aged population is to be supported by shrinking population at economically active age group. Aged population need to be supported in many aspects such as social, economic, and health support etc. It is important to understand the aging issue in the proper demographic and national context.

As the number of senior citizen has been increasing, it would natural concern to take care and providing necessary goods and services to those senior citizens who can not manage themselves and needs others support. The State should take responsibility to protect the rights of old by providing essential services and facilities, and their valuable experiences, skill, knowledge and capability could be mobilized for the national development. The state should guarantee social and economic justice to these people. So there is need to ensure their social security. Social security is the general concept of providing welfare. Specially this article discusses on the process of aging and the policy issue related to social security of old age population in Nepal.

\section{Objective}

The overall objective of this article is to assess the process of aging and discusses on the policy issue related to social security of old age population In Nepal.

\section{Methodology and Data Source}

This paper follows descriptive and analytical method based on the secondary data collected by the CBS and MoHP as conducted national level survey known as Nepal living Standard survey, 2011 and National Demographic Health Survey, 2011. The data from these sources are used to analyze the trend and process of aging and social security system in Nepal. Further more this paper is based on review of literature mainly books, journal, articles, policy documents and reports.

\section{Significance of the Study}

This study is based on quantitative analysis of aging process and social security system in Nepal. A basic understanding about theses aspects are beneficial to readers, teachers, researchers and other stakeholder.

\section{Ageing in Nepal:}

Nepal has adopted the definition of WHO, defined old as a person, above 60 years of age. Aging is an emerging issue in Nepal. The older population of the country is increasing both in terms of absolute number and as proportion of total population. It is accounted that 2.1 million elderly inhabitant constitutes 8.1 percent of the total population in 2011, which increased from 5.8 percent in 1991 . The 
elderly population in Nepal is growing steadily at the rate of 3.77 percent per year which was three times higher then the annual population growth rate(1.35\%) during 2001-2011. Table1

Table 1: Population Growth Rate and Elderly Population Growth Rate

\begin{tabular}{cccc}
\hline $\begin{array}{c}\text { census } \\
\text { year }\end{array}$ & $\begin{array}{c}\text { proportion of } \\
\text { population } \mathbf{6 0}^{+}(\mathbf{\%})\end{array}$ & $\begin{array}{c}\text { old age growth } \\
\text { rate(\%) }\end{array}$ & $\begin{array}{c}\text { annual population } \\
\text { growth rate }\end{array}$ \\
\hline 1991 & 5.8 & 2.25 & 2.08 \\
2001 & 6.5 & 3.19 & 2.25 \\
2011 & 8.1 & 3.77 & 1.35 \\
\hline
\end{tabular}

\section{Source:CBS,2014}

Nepal has experienced lower birth rate, and declining mortality rate with increasing life expectancy. Similarly other indicators of aging like old age dependency ratio, index of aging and median age of population are gradually increasing over the year. which subsequently will result in an greater proportion of elderly individuals in the population. Table 2

Table 2: Demographic Situation of Aging in Nepal

\begin{tabular}{ccccccc}
\hline $\begin{array}{c}\text { census } \\
\text { year }\end{array}$ & TFR & IMR/1000 & $\begin{array}{c}\text { life } \\
\text { expectancy }\end{array}$ & $\begin{array}{c}\text { old aged } \\
\text { dependency }\end{array}$ & $\begin{array}{c}\text { index of } \\
\text { aging }\end{array}$ & $\begin{array}{c}\text { median } \\
\text { age }\end{array}$ \\
\hline 1991 & 4.8 & 97 & 54.27 & 11.2 & 13.6 & 18.4 \\
2001 & 4.1 & 64 & 60.34 & 12.2 & 16.7 & 20 \\
2011 & 2.6 & 46 & 66.6 & 14.3 & 22.3 & 22.3 \\
\hline
\end{tabular}

Source: CBS,2014 and NDHS, 2011

Nepal is in the phase of age structure transition with a large proportion of young working age population. This phase is also commonly known as the phase of youth bulge, demographic dividends or the window of opportunity. This present phase and the consistent increment in the share of older age population over the year signifies that the elderly population will continue to increase in the years to come. Nepal's population divided into three broad age categories are presented in Table 3.

Table 3: Population by Age Structure, Nepal,1991---2011 (\%)

\begin{tabular}{cccc}
\hline census year & 0---14 years & 15---59years & 60+years \\
\hline 1991 & 42.4 & 51.8 & 5.8 \\
2001 & 39.3 & 54.1 & 6.5 \\
2011 & 34.9 & 56.9 & 8.1 \\
\hline
\end{tabular}

Source:CBS,2014

Table shows more than half of the population falls in the 15-59 years category which conforms that the Nepali population is primarily young. The large proportion of youth also indicates that the population is gradually aging over the years. In a few decades the youth will shift into the category of 60 and above, there by increasing the proportion of the aged population. Thus the decreasing population 
of children and the increasing proportion of the working age and thee older population affirms that Nepal is under going age structure transition and the population is gradually aging.

Hence all of these aspects reveal that the population aging is rising steadily in Nepal. The transition of elderly people will have achieved in Nepal as like other developing countries earlier then developed countries. population aging generates many challenges and spark concern about the pace of future economic growth, the operation and financial integrity of health care and pension system and the well being of the elderly. In response to tackle these issues and to address their needs the Government has developed the social security policy, plan and acts.

\section{Social Security System in Nepal.}

social security refers to the financial support action programme of Government intended to promote welfare of the population. It is potentially directed to vulnerable segment of the society such as children, the elderly, the sick and the unemployed. It is the tool for the government to take care of well being of it's citizen. The concept of social security, as presented in the Universal Declaration of Human Right explain that everybody has right to social security in order to ensure a life with justice, equality and dignity.

The global environment for developing social security service emerged during the Post World War II recovery plan for global socio economic situation. Germany was the first nation to adopt modern social security scheme with the introduction of old age social insurance programme in 1989 A.D. In 1952, the ILO adopted the social security Minimum Standard Convention 102 and in 2001, it introduced a global campaign on social security and coverage for all. Modern welfare state ought to provide economic and social security in the form of facilities and respect to senior citizens.(Mathema,2012)

Talking about the historical development of social security in the contest of Nepal the Hindu and Buddhist religion provides basic activities of social security such as giving alms, philanthropic health and education services. In ancient periods during Lichhabi, Malla and even Rana regime social security policy of Nepal was primarily based on feudalistic and dictatorial system which depends upon order of the head of state. The end of Rana family regime through peoples movement followed historical introduction of Democracy in the country in 1951. The country adopted the constitutions and formulated acts and regulation to turn the state activities under the rule of law.(Mathema,2012)

Nepal as the member state of UN and as a signature country of UDHR and various other important international conventions, has international commitment to develop social security services in line with its constitutional provisions of the country. Government of Nepal has formulated a National policies, on aging and the problem of elderly have been addressed at a level in various act and their regulations for elderly people in Nepal.

\section{National Policies Addressing the Need of Social Security of Elderly in Nepal}

\section{The Constitution Of Nepal}

The Constitution of Nepal 1990 had recognized social security as a state responsibility and the Interim Constitution of Nepal2007 and Constitution of Nepal 2015 has ensured social security as a fundamental right of the people. 


\section{Five year Periodic Plan}

In the periodic plans of Nepal, from the First Five year plan to Eight year plan period 19551997 AD programmes relating to social security were included under respective sector programme. The Ninth Plan (1997-2002) made notable deviation by including social security chapter addressing needs of helpless, disabled widows, senior citizen. It focused on granting monthly allowance and facilities, provision of geriatric ward in all zonal hospital, concession for senior citizen in hospital including private ones. Tenth Plan (2002-2007) emphasized on guaranteeing social security provision for the senior citizens.

Three year Interim Plan(2007/08 - 2009/10) for the first time incorporated senior citizen as a separate chapter. It focused on legal provision to ensure the rights of senior citizen ,their participation in relevant institution, establishment of senor citizen fund to run the programme for senior citizen. The plan (2011 -2013) has adopted the separate vision mission, strategy and intervention for senior citizen.

The Civil Code1963, has provisions for elderly people in its section on property rights distribution. In Civil Code1963 sec. 10, it is stated that, "If the parents want to live with a particular son or daughter, it has to be clearly stated in the Bandapatra (the legal note on property distribution) and that son and daughter should take care of the parents.

Local Self Governance Act 1999, under the heading of duties, rights, and responsibilities of village development committee in the Local Self Governance Act 1999, there is a provision for protection and development of orphan children, helpless, women, older people and disabled.

Senior Citizen Policy 2058 is a key policy document of the government toward elderly in the country. It has envisaged incorporating economic benefit, social security, health service facilities and honor, participation and involvement, and education as well as entertainment aspects to support the elderly people in having prestigious livelihood.

The National Plan of Action, 2062 developed for senior citizens deals with various aspects such as economic and social security, health and nutrition, participation and involvement, education and entertainment and legal condition and reforms. It identifies the elderly as one of its main target group.

Senior Citizen Act 2063 developed to ensure the social economic and human rights of senior citizen. the Act has provision for the establishment of the senior citizen welfare fund at Central level and District Senior Citizen Welfare Committee at the community level for the protection and social security of senior citizen. it has created Care Centres and Day Service Centre for the senor Citizen and also provision to provide allowance. The law is regarded a significant in respect to provide social protection for senior citizen.

Senior Citizen Regulation 2065 provides guidelines for the implementation of the Senior Citizen Act. It also provides the detailed procedure to be fulfilled to established and run geriatric home, old age home, and day care centre in the country. 
In relation to senior citizen Nepal is also committed to the United Nations Principles for Older Persons 1991,Macau Plan of Action of Aging for Asia and the Pacific 1999 and Madrid International Plan of Action on Aging,2002 to ensure the social security of elderly persons. In accordance with these commitment government of Nepal has formulated and promulgated separate policies, act, rule and regulation for elderly people in Nepal.

\section{Social Security Programme and Activities}

Nepal is poor country where old people is more likely to need State support in their old age, realizing this Government of Nepal has formulated various schemes act and programme to address their issues and various needs such as:

- Old Age Allowance: The Government of Nepal has introduced the Universal Old Age Allowance Programme in the FY1994/95. It is the noncontributing social assistance to old people. The rate of Old Age allowance at the introduction Rs 100and increased to Rs.500, Rs. 1000 and now Rs. 2000 to all elderly people above 70 years.

- The government has pension scheme for retired public servants and their widows and children.

- Old Age Home and day Care Centre: Established Pashupati Bidharasram and Ashram for old people, day care centre.

- Establishment of Senior Citizen Welfare Fund at the Central level and District Senior Citizen Welfare Committee in the leadership of DDC and at the VDC/Municipality.

- The government has adopted The Jeshtha Nagarik Swasthya Upachar Sewa Karyakram Karyanyowan Nirdeshika 2061 and has provisioned to establish Jeshtha Nagarik Swashthopachar Kosh in each district to deliver health care services to the elderly.

- Efforts will be made to make available of some concession in the fees for treatment in private nursing homes and clinics.

- Started Social Service unit in 8 hospitals and geriatric ward in three hospitals up to zonel hospitals, free health services for the treatment of some diseases.

- Mobilization of NGO or Civil Society and coordinating with other agencies such as GOs, UN, INGOs National NGOs a for welfare of senior citizen in Nepal

- In public transportations the people above the age of 60 years are legally provided the discount of $50 \%$.

- National level survey on ageing is to be conducted.

- Strong Commitment to Madrid International Plan on aging and other International Plan of Action, Declaration.

\section{Conclusion}

Nepal is already in the process of population aging. The older population of the country is increasing both in terms of absolute number and as the proportion of total population which is growing faster then the annual population growth rate. Nepal has experienced lower birth rate, and declining mortality rate with increasing life expectancy. More then half percent of total population concentrated in working age group. The large proportion of youth also indicates that the population is gradually aging over the year. It also shows that Nepal is in the phase of age transition. 
population aging generates many challenges on social economic and health care system. In response to tackle these issues and to address their needs the Government of Nepal has formulated separate policies and security programme including old age allowance, old age pension for civil servant, old age home and other health related facilities and also committed to the various regional and international convention to promote welfare for senior citizen of the country. The policies on Senior citizen in Nepal have centered around the providing welfare particularly centering on social security. The limited provision of welfare facilities provided by the Government have often been obstructed by the lack of implementation of the policies.

\section{References}

Central Bureau of Statistics (2014).Population Monograph of Nepal. Kathmandu. Central Bureau of Statistics.

Government of Nepal (1999).Local Self Government Act (1999).Ministry of Law and Justice. Law Books Management Book, Kathmandu.

Government of Nepal (1963). Civil Code(1963).(Available at http;//www.lawcommission.gov.np)

Government of Nepal (2058). Senior Citizen Policy: Kathmandu: Government of Nepal.

Government of Nepal.(2062). National Plan of Action on Ageing (2062).Government of Nepal.

Government of Nepal (2065). Senior Citizen Act (2063) and Regulation (2065).Government of Nepal.

Government of Nepal (2072).Constitution of Nepal,2072.Kathmandu: Government of Nepal. Government of Nepal.

GoN(2002),Ninth Plan, Tenth plan (2007), Interim Plan(2011) and Interim Plan(2013) (Available at http://www.npc.gov.np)

MathemaPadma(2012).National Social Security Policy: A Reality Need for Nepal.

Ministry of Health and Population. New ERA, and Macro International Inc. (2011). Nepal Demographic and Health Survey,2011. Kathmandu. Family Health Division, Ministry of Health: New ERA/ ORC Macro.

UNFPA and Help Age International (2012).Ageing in the Twenty-First Century: A Celebration and A Challenge. UNFPA and Help Age International.

United Nation(2015). World Population Ageing .United Nation. 